Metallophysics and Advanced Technologies

металофіз. новітні технол.

Metallofiz. Noveishie Tekhnol.

2020 , vol. 42 , No. 11 , pp. $1525-1535$

https://doi.org/10.15407/mfint.42.11.1525

Reprints available directly from the publisher

REACTOR AND AEROSPACE METALS SCIENCE

PACS numbers: 28.41.Qb, 28.52.Fa, 28.90.+i, 81.20.Ym, 82.45.Hk

\title{
Development of Process for Producing Zirconium Powder of Nuclear Purity
}

\author{
A. P. Mukhachov and O. A. Kharytonova"
}

Center of Chemical Technology of Academy of Engineering Sciences of Ukraine, 179 Anoshkin Ave., 51917 Kamianske, Ukraine,

"Dniprovsk State Technical University,

2 Dniprobudivska Str.,

51918 Kamianske, Ukraine

The paper presents the results of studies of the purification process of zirconium metal powder from carbon obtained by electrolysis of molten salts. As shown, the use of a pulsating column with a distribution nozzle allows organizing a continuous process of washing zirconium powder from salts and carbon particles, reducing the number of technological operations, the consumption of water and reagents, automating and mechanizing the process of producing zirconium powder of nuclear purity. The quality of the powder complies with the ASTM standard, and the new equipment successfully solves the problems of economy and ecology.

Key words: cathode deposit (CD), electrolysis, zirconium powder, electrolyte, reactor, pulsation column, cathode product, intensification, leaching, ammonium carbonate, potassium carbonate, carbon.

В роботі викладено результати досліджень процесу очищення металевого порошку цирконію від Карбону, отриманого при електролізі розплавлених солей. Показано, що застосування пульсаційної колони з розподільною насадкою дозволяє організувати безперервний процес відмивання порошку цирконію від солей і вуглецевих частинок, скоротити число технологічних операцій, витрату води і реагентів, автоматизувати і механізувати процес виробництва порошку цирконію ядерної чистоти. Якість порошку, відповідає стандарту ASTM, а нове обладнання успішно вирі-

Corresponding author: Anatoly P. Mukhachov

E-mail:map45@ukr.net

Citation: A. P. Mukhachov and O. A. Kharytonova, Development of Process for Producing Zirconium Powder of Nuclear Purity, Metallofiz. Noveishie Tekhnol., 42, No. 11: 1525-1535 (2020), DOI: 10.15407/mfint.42.11.1525. 
шує питання економіки та екології.

Ключові слова: електроліз, порошок цирконію, електроліт, реактор, пульсаційна колона, катодний продукт, інтенсифікація, карбонат амонію, карбонат калію, Карбон.

(Received July 27, 2020; in final version, August 20, 2020)

\section{INTRODUCTION}

The zirconium electrolysis method is an alternative to the process of magnesium-thermal reduction. Electrolysis makes it possible to obtain a highly pure and competitive metal with nuclear properties required by the nuclear industry. On the cathode from the chloride-fluoride electrolyte precipitates zirconium powder, crystallizes the electrolyte salts, capturing carbon particles, a cathode product (CP) is formed. High solubility of zirconium salts in carbonate media allows to change the acid medium during the leaching of fluoride salts and to protect the purity of the powder from corrosion. The equipment plays an important role in the process of extracting the powder.

The batch reactor allows sequential salts leaching from CP and separation of powder and liquid phase by decantation. To remove carbon, flotation machines are used, while up to $25 \%$ of the powder leaves with graphite and requires processing.

Large-tonnage production requires larger size of reactors. They have a disadvantage: stagnant zones, which reduce the effectiveness of mass transfer processes. This fact leads to an increase in the contact time of the reactants with the powder, productivity decrease and reagent consumption increase, which increases the cost of $\mathrm{Zr}$.

The ways of intensifying the leaching process are described in the paper [1]. The transition from periodic devices to continuous devices with pulsation increases productivity, reduces the consumption of reagents and the laboriousness of production. Their difference is high productivity, low energy consumption, simplicity of design. Intensification of the chemical process in the columns is carried out by imposing the vibrational (reciprocating) motion on the fluid volume, which is equally distributed over the cross section. The pulse generator is a pulsator. It is located outside the apparatus and operates in compressed air. Pulsation columns reduce the cost of $\mathrm{Zr}$ powder, reduce its losses, successfully solve energy problems, eliminate the loss of chloride-fluoride reagents.

Benefits and advantages of pulsating technology are described in the paper [2]. The basis for its calculation and design are described in the paper [3]. The examples of pulsating equipment application for separation and washing leaching of iron powder are given in the papers [4-6]. 
The purpose of the experiment is to produce a cheap and pure zirconium powder in accordance with ASTM, suitable for the products of the reactor core, to determine the technical and economic parameters of the CP processing.

\section{TECHNIQUE OF THE EXPERIMENT}

$\mathrm{CP}$ was fractioned to $5.0 \mathrm{~mm}$, crushed to the size of $1.0 \mathrm{~mm}$, in the environment of $8 \%$ potassium carbonate solution. To determine the optimal modes of leaching processes and the separation of zirconium powder, laboratory tests on the kinetics and distribution of the residence time of particles smaller than $1.0 \mathrm{~mm}$ were carried out.

The studies were carried out in the thermostat. The solid material was separated from the liquid on the Shot filter. The sedimentation velocity of the solid phase particles in the stagnant solution was determined by the method described in the paper [4]. The cylindrical vessel was used to determine the dependence of the number of settled particles on the time $\sigma\left(\tau_{0}\right)$. The cylinder was calibrated in order to determine the volume of solid phase after settling. CD is a polydisperse material, therefore the settling rates of different fractions and monoparticles differ.

The distribution density $f\left(\tau_{0}\right)$, where $\tau_{0}$ is the settling time of the particles in the solution at a liquid column height of $1.0 \mathrm{~m}$, was determined experimentally. The extreme admixture in zirconium is carbon, the sedimentation velocity of which is necessary to know. The average residence time of the particles and dispersion is calculated according to the accumulation curve [7], or from the functions $F\left(\tau_{0}\right)$ and $f\left(\tau_{0}\right)$ [8].

Knowing the kinetics of the process and the distribution of the residence time of the powder particles in the apparatus, taking into account the losses of zirconium, the optimum velocity of the upstream is calculated.

The laboratory research facility was made of glass with a total height of $2.0 \mathrm{~m}$, with a diameter of the packed part of $56 \mathrm{~mm}$ (Fig. 1). The number of operations on the $\mathrm{CO}$ reprocessing was reduced to simplify the research. They included the solid phase processing with $8 \%$ solution of potassium carbonate, powder washing with $10 \% \mathrm{HCl}$ and washing from acid.

After studying the kinetics of the process, the residence time of the solid phase in carbonate and acid media was determined in order to calculate the height of the working area of the column. CP batch of $70 \mathrm{~kg}$ was selected to conduct technological tests. Zirconium powder was passed through the apparatus three times, while maintaining the conditions of the experiment. Zirconium powder samples (at least 6 samples per each processing cycle) were taken at the column outlet in $\mathbf{1 5}$ minutes after the beginning of the experiment. The powder was sepa- 
rated from the liquid, dried and analyzed.

Based on the analysis of the data on the extraction of zirconium powder, its actual losses and the specific productivity of the pulsation column were determined. Considering the flows and the relative volume content of the solid phase, the diameter of the column and its height were calculated.

\section{RESULT AND DISCUSSION}

The pilot plant (Fig. 1) consists of a column reactor, loading and unloading systems of reagents.

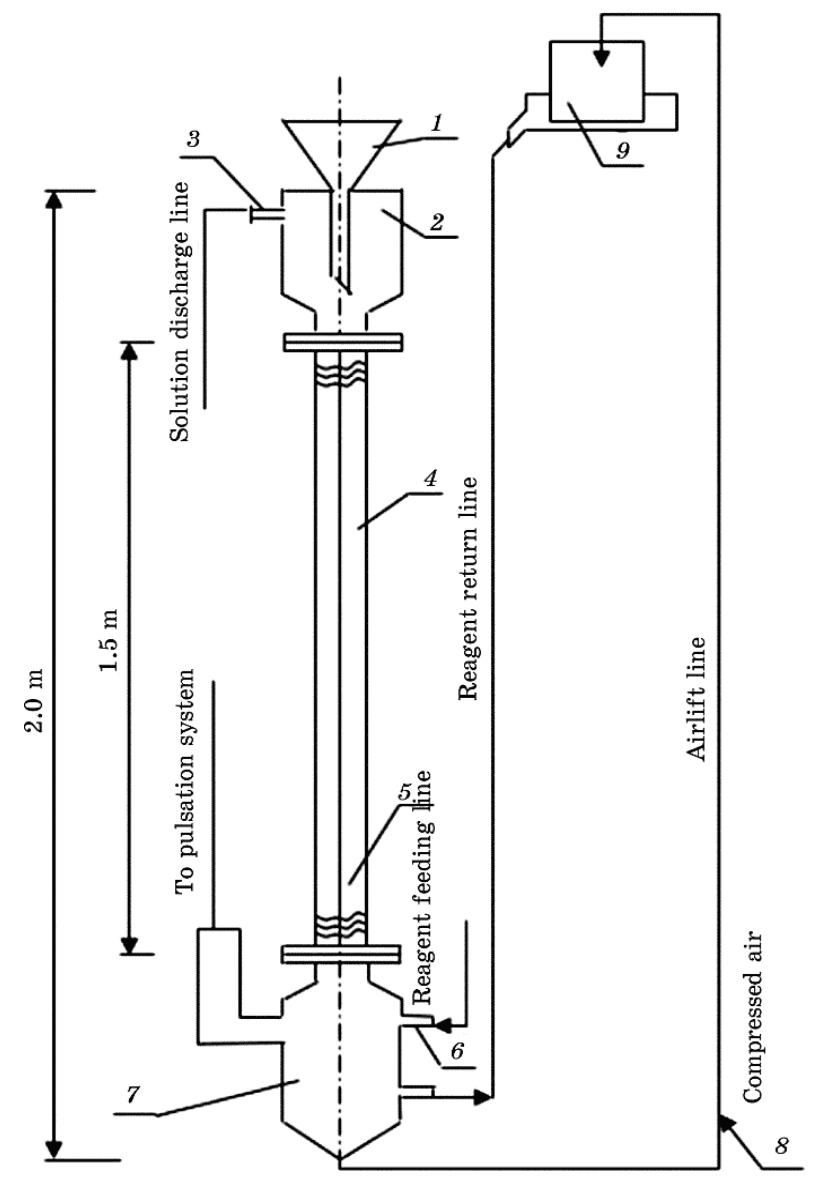

Fig. 1. Scheme of the pilot plant: 1-funnel for product loading, 2sedimentation zone, 3-connection of the solution drain, 4-column body, 5 -Teflon attachment with holes of $\varnothing 5 \mathrm{~mm}, 6$-input of the initial solution, 7-lower zone of sedimentation, 8-airlift, 9 -separating container. 
The reaction mass is brought into reciprocating motion by means of pulsation system. The oscillation frequency is 78 per minute, the amplitude of the oscillations (double amplitude) $A=10-12 \mathrm{~mm}$, the pulsation intensity $I=f A=1000 \pm 100 \mathrm{~mm} / \mathrm{min}$.

The column operates in the weighted layer mode. The solid phase moves like a uniform stream, flowing from the plate to the plate given the pulsation. In the distribution attachment the holes are arranged in a circle. The holes are drilled at an angle of $45^{\circ}$ to the horizontal plane. They make it possible to ensure a good distribution of reagents on the cross section, which prevents the formation of stagnant zones. In the package, the plates with the direction of clockwise and counter clockwise alternate, the pulsation column operates in a counter-current phase mode. This supports the high rate of dissolution, leaching and washing processes through the whole apparatus.

As a rule, the residence time of solid material in the pulsation column is 1-2 orders of magnitude less than in agitated reactor. Reagent consumption is reduced due to less dilution of solutions. The pulsating device can also work in the classification mode when the separation of solid material into fractions takes place. The efficiency of the classification is determined by the constancy of the upstream velocity. If there is no need to carry out a classification, the upstream velocity is selected on the minimum powder losses. Laboratory studies of the CP processing showed that it is impossible to achieve carbon reducing in zirconium to the required level $(0.03 \%)$ by decantation.

To remove carbon, a separate operation, flotation, is required. $\mathrm{Ki}$ netic studies made it possible to calculate the necessary residence time of the powder in a pulsation column. It is 4 minutes in operations of carbonate and acid treatment.

To calculate the apparatus, we used the particle distribution density $f\left(\tau_{0}\right)$. For this purpose, the dependence of solid phase accumulation from \% settled particles over time was measured experimentally. The function $F\left(\tau_{0}\right)$ is a derivative of the function $v\left(\tau_{0}\right)$ and, in physical sense, is analogous to the $F$-function used in hydrodynamics [8].

It varies from 1 to 0 , the value of $F\left(\tau_{0}\right)$ for a given $\tau_{0}$ is equal to the fraction of particles having the residence time $f\left(\tau_{0}\right)$. The derivative of $F\left(\tau_{0}\right)$ has the following physical meaning: the relative number of particles having a residence time from $\tau_{0}$ to $\tau_{0}+d \tau_{0}$ is equal to $f\left(\tau_{0}\right) \cdot \tau_{0}$.

Figure 2 shows typical curves of these functions for a polydisperse material.

The average residence time of particles, as well as their dispersion, is calculated according to the accumulation curve [5] or the functions $F\left(\tau_{0}\right)$ and $f\left(\tau_{0}\right)$.

$$
\tau_{0}=\int_{0}^{\infty} \tau_{0} f\left(\tau_{0}\right) d \tau_{0}=\int_{0}^{\infty} F\left(\tau_{0}\right) d \tau_{0}
$$




$$
\sigma_{\tau_{0}}^{2}=\int_{0}^{\infty}\left(\tau_{0}-\tau_{0}\right)^{2} f\left(\tau_{0}\right) d \tau_{0}
$$

Let's estimate, at known speed of an upstream, the entrainment of a solid material, taking into account functions $F\left(\tau_{0}\right)$ and $f\left(\tau_{0}\right)$.

The solid phase delay at a given solution velocity is calculated by the formula:

$$
\Omega=\frac{Q \alpha}{\rho S} \int_{0}^{Q} \frac{f\left(\tau_{0}\right) d \tau_{0}}{\left(\frac{1}{\tau_{0}}-v_{P}\right)},
$$

where $Q$ is the flow rate of the solid phase in $\mathrm{kg} / \mathrm{h}, \rho$ is specific gravity of solid material in $\mathrm{kg} / \mathrm{m}^{3}, S$ is the cross-sectional area of the column in $\mathrm{m}^{2}, v_{P}$ is the linear velocity of the solution in $\mathrm{m} / \mathrm{h}$

$$
Q-0.8^{1 / v} \text {. }
$$

Figure 3 shows the accumulation curves for 4 fractions of the insoluble CD part, the total curve for the entire fraction is $1 \mathrm{~mm}$, and the accumulation curve for graphite, the fraction is $1 \mathrm{~mm}$. The curves

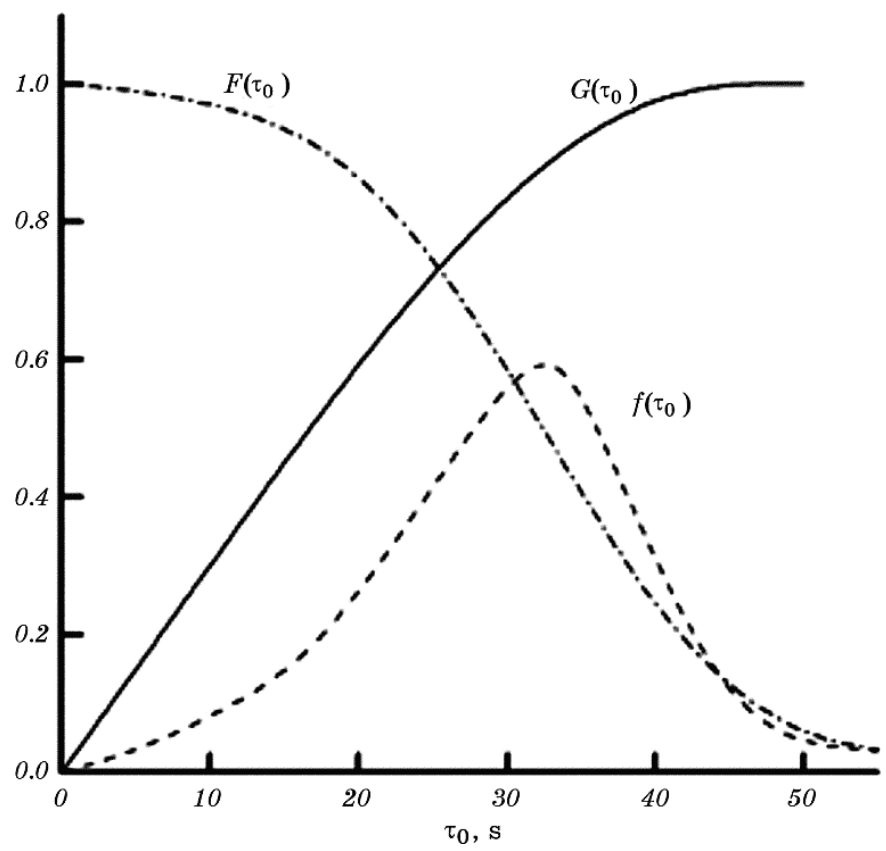

Fig. 2. Typical curves of accumulation functions $G$, the residence time distribution $F$, the distribution density $f$. 
were taken when using $8 \%$ potash solution. They are recalculated according to the \% content of each fractions, the graphite accumulation curve is given without recalculation.

Figure 4 shows the $F\left(\tau_{0}\right)$ curves for the solid phase and graphite, the Fig. 5 presents the curves $f\left(\tau_{0}\right)$.

Curve processing, construction of graphs and other calculations were carried out on the digital computer 'Nairi-S', the distribution function of the residence time was constructed for graphite crushed separately. From the comparison of the curves, it can be argued that the complete separation of zirconium and graphite (without zirconium losses), by hydraulic classification method is impossible.

For example, at an upstream velocity of $v_{P}=200 \mathrm{~m} / \mathrm{h}\left(\tau_{0}=18 \mathrm{~s} / \mathrm{m}\right)$, the particles of $1 \mathrm{~mm}$ fraction will be completely separated from the zirconium powder, but the metal losses will be $\approx 23 \%$. Real metal losses are higher than estimated losses due to fluctuations in the flow velocity at the top of the apparatus, while the fractional composition of the solid will change. The recommended upstream velocity will be in the range of $80-140 \mathrm{~m} / \mathrm{h}$, with the metal loss of $\approx 15 \%$, with the powder losses in the periodic reactors at the level of $20 \%$.

As a result of the research, it was determined that the average residence time of the powder in carbonate and acid media is $\tau_{0} \sim 12 \mathrm{~s}$, for

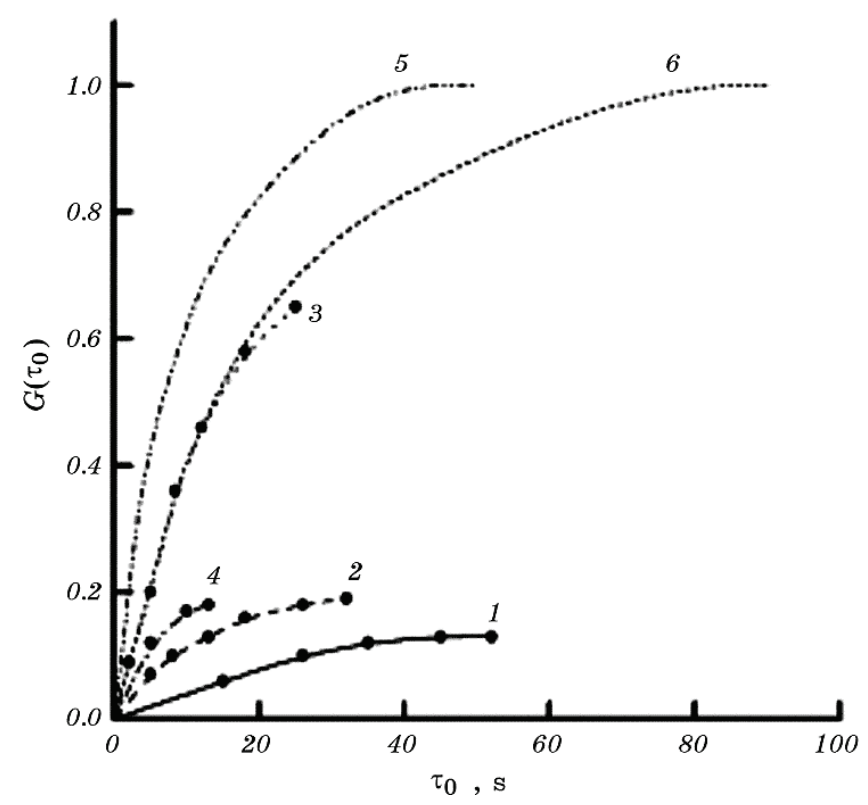

Fig. 3. Accumulation curves for the insoluble part of the cathode deposit: $1-$ fraction-0.063 $\mathrm{mm}, 2$-fraction- $0.18+0.063 \mathrm{~mm}, 3$-fraction-0.5 +0.18 $\mathrm{mm}, 4$-fraction $-1+0.5 \mathrm{~mm}$. 
graphite $\tau_{0}=33 \mathrm{~s}$, the dispersion is equal to

$$
\sigma_{\tau_{0}}^{2}=0.27 \text { and } \sigma_{\tau_{0}}^{2}=0.53 \text {. }
$$

The average residence time of the solid phase at the upstream velocity $v_{p}=100 \mathrm{~m} /$ hour was $\tau=22-24 \mathrm{~s}$, the delay (at the same velocity and specific capacity of the apparatus $\approx 20 \mathrm{t} /\left(\mathrm{m}^{2} \cdot \mathrm{h}\right)$ for zirconium) $\Omega=$ $2.0 \%$.

The height of the working area of the apparatus at the stages of carbonate and acid treatments should be equal to

$$
H \approx \frac{t_{\mathrm{pr}}}{\tau}=\frac{240}{23} 10 \div 12, \mathrm{~m},
$$

where $t_{\mathrm{pr}}$ is necessary processing time, $\tau$ is the average residence time of solid material at a given solution velocity.

The interaction of potassium fluozirconate with potash is described by the equation

$$
\mathrm{K}_{2} \mathrm{ZrF}_{6}+2 \mathrm{~K}_{2} \mathrm{CO}_{3}=\mathrm{K}_{2}\left[\mathrm{ZrF}_{2}\left(\mathrm{CO}_{3}\right)_{2}\right]+4 \mathrm{KF} .
$$

The schematic processing diagram for the cathode deposit reprocessing is shown in Fig. 6.

The particles of insoluble salts were observed in the solution, after the 1-st stage of the carbonate treatment. This is explained by the melt

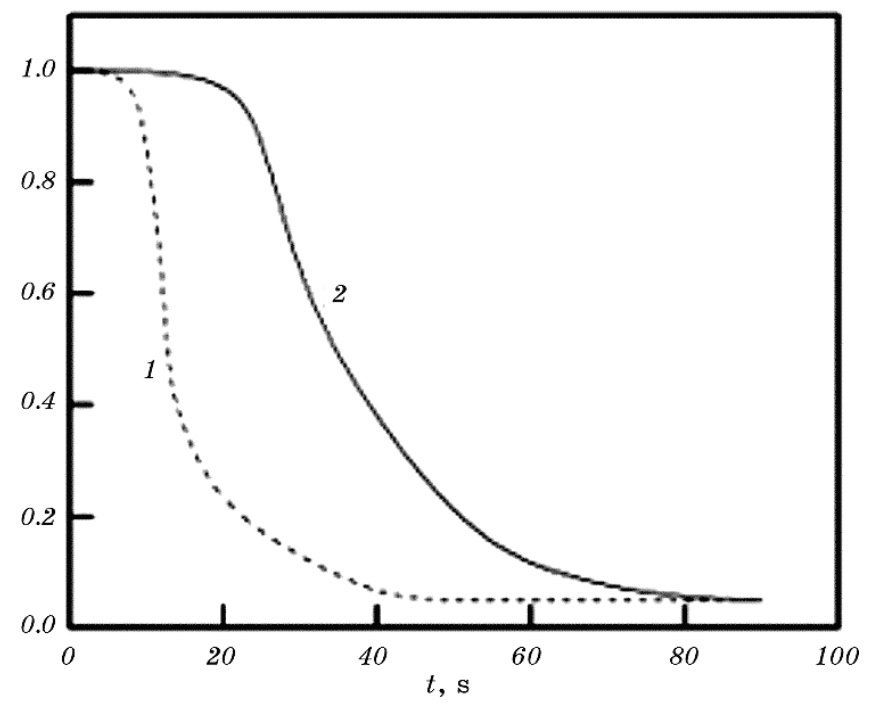

Fig. 4. Distribution of residence times of particles of solid material: 1 zirconium (fraction-1 $\mathrm{mm}), 2$-graphite (fraction-1 $\mathrm{mm}$ ). 


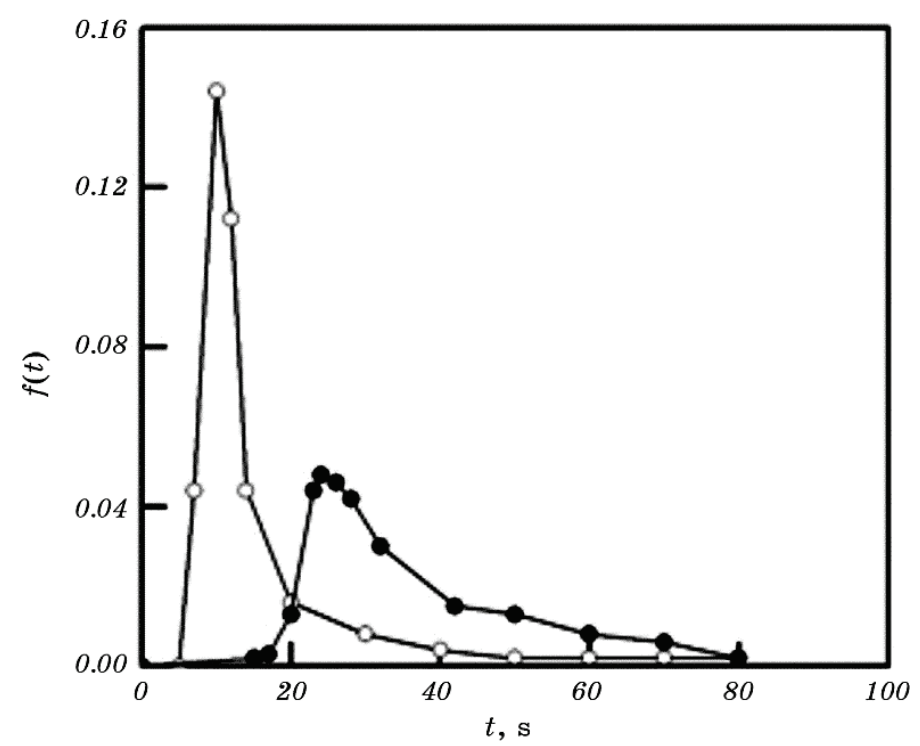

Fig. 5. Distribution density of residence times of particles of solid material: ○-zirconium (fraction-1 $\mathbf{m m}$ ), •-graphite (fraction-1 $\mathbf{m m}$ ).

contact with a saturated solution and the removal of individual melt particles by the upstream from the upper zone of the apparatus together with mechanical impurities and a fine fraction of the zirconium powder. The content of impurities in the powder at the various stages of their processing was minimal. After two cycles of water treatment, only the content of silicon was markedly reduced. The time of acid powder treatment has an effect on the purity of the product. Its increase in 3 times led to decrease in the carbon and silicon content in the powder (2-3 times).

The content of impurities in the zirconium powder (after the second water treatment) corresponds to ASTM, which makes it possible to exclude the flotation operation of the powder. The implementation of the counter-current phase principle can reduce the specific consumption of the water phase to $2.4 \mathrm{~m}^{3}$ per tonne $(\mathrm{t})$ of $\mathrm{CP}$ and reduce the concentra-

TABLE 1. Comparative data of CP reprocessing.

\begin{tabular}{c|c|c|c|c|c}
\hline \multirow{2}{*}{ Equipment } & \multicolumn{5}{|c}{ Specific reagent consumption, $\mathrm{kg} / \mathrm{t}$} \\
\cline { 2 - 6 } & Water & Ammonia & Carbonate & Acid & $\begin{array}{c}\text { Specific performance, } \\
\mathrm{t} /\left(\mathrm{m}^{2} \cdot \mathrm{h}\right)\end{array}$ \\
\hline Reactor & 36.0 & 20.0 & 100.0 & 60.0 & 2.0 \\
Column & 6.5 & 2.0 & 15.0 & 15.0 & 20.0 \\
\hline
\end{tabular}




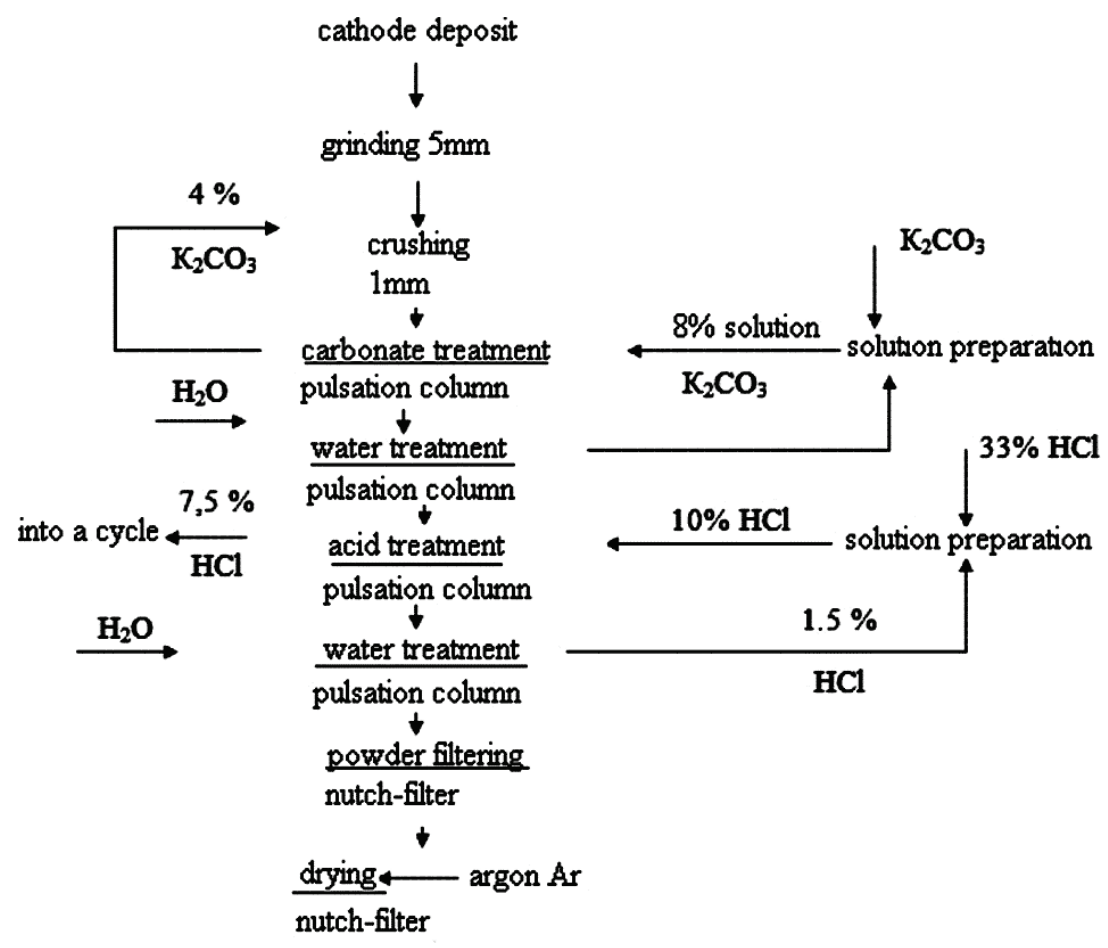

Fig. 6. Instrument flow diagram of $\mathrm{CO}$ reprocessing.

tion of hydrochloric acid from $27 \%$ to $10 \%$. The results of the experiments are given in Table 1.

As can be seen from the data given in Table 1, the technical and economic efficiency of the column is significantly higher than that of the technology based on the use of batch reactors, which makes it possible to intensify the process of powder production fivefold. The specific productivity of the pulsation column is one order magnitude higher than the productivity of batch reactors. The withdrawal of fine fractions of zirconium powder into the dissolution stage decreased from $20 \%$ to $15 \%$. The size of the powder averaged $0.26 \mathrm{~mm}$ at a density of 5 $\mathrm{g} / \mathrm{cm}^{3}$.

\section{CONCLUSIONS}

1. Testing of a pulsation column with a distributional head for producing zirconium powder from the CD showed its higher efficiency compared to reactors with batch devices.

2. The achieved intensification of powder producing in the pulsating column makes it possible to increase its specific productivity, from 2.0 
to $20.0 \mathrm{t} /\left(\mathrm{m}^{2} \cdot \mathrm{h}\right)$.

3 . Based on the results obtained, instrument-flow diagram for zirconium powder production using pulsation columns was developed.

4. The zirconium powder produced in pulsation column meets the requirements of ASTM, its output was $85 \%$, the powder size was $0.26 \mathrm{~mm}$, its density was $5 \mathrm{~g} / \mathrm{cm}^{3}$.

5 . The water flow in the pulsation column was reduced from $90.0 \mathrm{~m}^{3}$ to $2.4 \mathrm{~m}^{3}$ per 1 tonne of CD.

6 . The replacement of ammonium carbonate with potassium carbonate makes it possible to create a closed technological cycle for potassium chloride and exclude the burial of chloride effluents.

\section{REFERENCES}

1. A. S. Medvedev, Vyshchelachivanie i Sposoby Ego Intensifikatsii (Moscow: MISiS: 2005) (in Russian).

2. S. M. Karpacheva, Sbornik Trudov I Vsesoyuznoy Konferentsii 'Pulsatsionnaya Apparatura v Narodnom Khozyaystve’ (Moscow: Atomizdat: 1979), vol. 1 (in Russian).

3. S. M. Karpacheva and E. I. Zakharov, Osnovy Teorii i Rascheta Pulsatsionnykh Kolonnykh Reaktorov (Moscow: Atomizdat: 1980). (in Russian).

4. E. I. Zakharov, V. F. Abramkin, L. M. Kamenik, A. Yu. Sakharov et al., Sbornik Trudov I Vsesoyuznoy Konferentsii 'Pulsatsionnaya Apparatura $v$ Narodnom Khozyaystve' (Moscow: Atomizdat: 1979), vol. 3, p. 78 (in Russian).

5. E. I. Zakharov, V. F. Abramkin, Yu. F. Korovin, A. L. Levchenko, et al., Sbornik Trudov I Vsesoyuznoy Konferentsii 'Pulsatsionnaya Apparatura $v$ Narodnom Khozyaystve' (Moscow: Atomizdat: 1979), vol. 3, p. 52 (in Russian).

6. S. M. Karpacheva, Yu. S. Zhilin, D. V. Roshchin, and V. M. Muratov, Sbornik Trudov I Vsesoyuznoy Konferentsii 'Pulsatsionnaya Apparatura v Narodnom Khozyaystve' (Moscow: Atomizdat: 1979), vol. 3, p. 3 (in Russian).

7. V. V. Kafarov, Metody Kibernetiki v Khimii i Khimicheskoy Tekhnologii (Moscow: Izd-vo 'Khimiya': 1971). (in Russian).

8. V. V. Kafarov et al. Voprosy Modelirovaniya Ekstraktsionnykh Kolonn s Pulsatsiey. Sbornik Zhidkostnaya Ekstraktsiya (Moscow: Izd-vo 'Khimiya': 1969), p. 29 (in Russian). 